UDC 574.55

Yu. G. Giginyak*, Dz. A. Lukashanets, O. I. Borodin, V. E. Miamin, V. M. Baichorov

State Research and Production Association "Scientific and Practical Center of the National Academy of Sciences of Belarus for Bioresources", 27 Academicheskaya Str., Minsk, 220072, Belarus

*Corresponding author: antarctida_2010@mail.ru

\title{
Energy content of sublittoral biologically-relevant resources in the East Antarctic seas
}

\begin{abstract}
Objective.To determine the energy value of several groups of the East Antarctic sea biota and identify potential calorific differences in the context of both taxa and ecological groups. Methodology. Sampling was carried out by traditional methods (benthic traps, diving gathering), and remote sampling was also applied (using remote-controlled underwater vehicles). The energy value of organisms is determined using wet burning methods. Results. The energy indicators of the main biological objects of the sublittoral of the three seas at the East Antarctica were determined for the first time. It has been shown that in the studied sublittoral regions of the Cosmonauts, Cooperation (more Sodruzhestva) and Davis seas, the dominant species of marine zoobenthos was the sea urchin Sterechinus neumayeri (Meissner, 1900). The caloric values of starfish, polychaetes, nemerteans, sponges, ascidia, holothurians, crustaceans, and some other taxa of marine biota were determined. It is shown that the content of organic matter in Antarctic species varies from $12-94 \%$, and caloric content - from $0.7-7.3 \%$ cal / mg dry matter, with the maximum values registered for amphipods and calanoids. The energy equivalents of marine zoobenthos per unit of bottom square have been calculated. The ratio equation of the caloric content of the substance of the studied object to the ash content is calculated. Conclusions. In general, we can conclude that the caloric values of marine zoobenthos in all three studied seas are close to each other. Furthermore, the caloric content of individual representatives of marine fauna varies significantly and, in general, depends on the quantity and quality of organic matter in certain species as well as on the season of year. The low-caloric representatives of the Antarctic flora and fauna correspond to the high substance ash levels of their body. Depending on the energy value significance, several groups of marine biota were represented, represented by various taxa.
\end{abstract}

Keywords: energy value, caloric content, marine biota, zoobenthos, phytoplankton, zooplankton.

\section{INTRODUCTION}

The principles of the energy approach in studying zoological systems are widely used in ecology (Platt, Irwin, 1973, Wacasey, Atkinson, 1987, Giginyak, 1979; Giginyak, 1983, Renk et al., 1985). In the framework of this approach, an important index is the energetic value or calorific content of the substance in studied organisms (Schaafsma et al., 2018). The information about the energy which contained in these organisms

Cite: Giginyak Yu. G., Lukashanets Dz. A., Borodin O. I., Miamin V. E., Baichorov V. M. Energy content of sublittoral biologically-relevant resources in the East Antarctic seas. Ukrainian Antarctic Journal, 2019. № 2 (19), 117-127. we obtain by expressing the hydrobionts body mass in calories, i.e. energy equivalent of the specimen (Giginyak, 2013). This is important for better understanding both the peculiarities of the ecosystem functioning in general and the valuation of different organisms as objects for consumers, in particular.

The caloric values of marine organisms that live in the sublittoral of the Davis, Cosmonauts and Cooperation (more Sodruzhestva) seas (all located in the East Antarctica) were determined. Particular attention was paid to representatives of three communities identified in the sublittoral - cryopelagic, subglacial and benthic. The energy value of the Antarctic phytoplankton (diatoms), seston, and fish was also deter- 
mined. As a result, some common features in various environmental groups were identified. Of particular interest is the determination of the caloric value of the permanent inhabitants of the benthal of the Antarctic seas, which potentially might serve as resource species, and in the future, in the region of the Belarusian Antarctic station especially can be harvesting objects.

\section{MATERIALS AND METHODS}

The analysis involved data obtained during the seasonal Belarusian Antarctic expeditions (hereinafter $\mathrm{BAE}$ ) at the Belarusian station "Vecherniaya Mount" (Cosmonauts Sea) and at the Russian station "Progress" (Cooperation Sea) during 2011-2017 (Giginyak, Borodin, 2011-2012; Giginyak, 2014). The article also includes data obtained by Yu.G. Giginyak during 1970-1972 at the "Mirny" station (Davis Sea) (Gruzov, Sheremetevskiy, 1973; Giginyak, 1975b). The material was collected by several ways: the bottom traps, by diving of light divers, as well as using the autonomous underwater remote-control device "Gnom" (Giginyak et al., 2018). To determine the energy value of animals the method of wet burning was performed - with using liquid reagents, i.e. potassium dichromate and sulfuric acid (unlike the dry method - when dry biological material is burned in an oxygen bomb without the use of liquid reagents). The use of wet burning method has greatly simplified and accelerated the processing of the test material. This method made it possible to calculate the caloric value of the sample by the value of oxidizability using the oxycaloric coefficient (the amount of released energy at a consumption of $1 \mathrm{mgO}_{2}$ ). The advantage of the method is that it allows you to determine the caloric content with sufficient accuracy $( \pm 3-5 \%)$ and, most importantly, requires the sample in the range of only 2-4 mg of dry matter (Giginyak, 1979; 1983).

During the whole period of biological investigations in the Antarctic, we determined the caloric content of representatives of 11 invertebrate taxa and the caloric content of phytoplankton (diatoms), seston and fish (more than 60 species in total).

The taxonomic identification of the marine fauna representatives was carried out by ourselves as well as

\section{8}

by colleagues from the Zoological Institute of the Russian Academy of Sciences (see acknowledgments) and based on morphology only.

\section{RESULTS}

\section{The results of the energy assessment of the studied seas fauna}

The caloric content is not a constant value for each species and specimen (Davis, 1993, Finlay, Uhlig, 1981). Its changes can be traced in the process of ontogenesis, starting already from the initial stage of egg development and up to definitive sizes. The energy in the eggs and body of the hydrobionts is used for the processes of respiration, the formation of the embryo, and for all types of growth - somatic, generative, and exuvial. Hence, as a result of the consumption of this energy during ontogenesis, the caloric content is constantly changing (Giginyak, Grusov, 2009).

Annual variations in water temperature in the Antarctic seas rarely exceed several (up to 4-5) degrees. Thus, there is a set of species that differ sharply in their ecological parameters and biotopic affiliation.

Below are the data on the caloric content of the most common and characteristic for the sublittoral Antarctic seas species belonging to different communities.

\section{Zooplankton and phytoplankton}

The caloric content of total plankton from the Antarctic seas reaches the highest values known in general for hydrobionts. It is about $8 \mathrm{cal} / \mathrm{mg}$ of organic matter.

Among the planktonic crustaceans, the main species are Calanus propinquus Brady, 1883, C. acutus Giesbrecht, 1902, Paraeuchaeta antarctica (Giesbrecht, 1902), Mysidacea spp. and some other species less significant in number and biomass. Their caloric value reaches $5.6 \mathrm{cal} / \mathrm{mg}$ of dry matter. The content of organic matter in the net plankton is about $60-80 \%$, which indirectly indicates the predominance of zooplankton organisms with high calorific value in it.

The caloric content of diatoms was only $0.8 \mathrm{cal} /$ mg of dry matter, with an ash content of about $75 \%$.

ISSN 1727-7485. Ukrainian Antarctic Journal. 2019, № 2(19) 
In general, the average calorific value of net plankton was found to be $5.6 \mathrm{cal} / \mathrm{mg}$ organic matter (4.5-7.9) with an ash content of about $30 \%$ (10.4-69.0\%).

C. propinquus, a representative of the Copepoda subclass, occurs in plankton throughout the year. Its caloric content reaches $7.0-7.3 \mathrm{cal} / \mathrm{mg}$ of dry matter or about $8.5 \mathrm{cal} / \mathrm{mg}$ of organic matter. We have shown the change in caloric content of these crustaceans in different seasons. A tendency towards an increase in the maximum calorific values was noted at the end of March - early April, i.e. at the beginning of the Antarctic winter, at the time of the ice formation on the sea (diatoms, the main food for the crustacean, begin to develop only with a decrease in solar radiation while the sea ice formation as well as shortening the day just contribute to it); and in mid-August - early September, i.e. at the time of the appearance of intrasea ice crystals where algae actively develop and whereto crustaceans rush for breeding and feeding.

\section{Ichthyofauna}

The caloric data of some species of ichthyofauna are partially presented in Tables 1 and 2 .

The energy value of individual parts of the body was determined for one of the most numerous representatives of the ichthyofauna of the shallow water zone of the Cosmonauts Sea,Trematomus bernacchii Boulenger, 1902.

The caloric content of the proximal part of trunk meat of T. bernacchii is about $4.1 \mathrm{cal} / \mathrm{mg}$ of organicmatter; meat of the spinal part is up to $4.8 \mathrm{cal} / \mathrm{mg}$ of organic matter, and of caudal part is up to $5.1 \mathrm{cal} / \mathrm{mg}$ of organic matter. Caloric content of the liver is 5.6 $\mathrm{cal} / \mathrm{mg}$, spleen $-5.1 \mathrm{cal} / \mathrm{mg}$, and heart $-4.5 \mathrm{cal} / \mathrm{mg}$ of organic matter. The maximum caloric values were observed in lipid deposits of internal organs -7.4 $\mathrm{cal} / \mathrm{mg}$ of organic matter.

As can be seen from the data presented in Table 2, the energy value of the muscles of adult fish reaches $4.6 \mathrm{cal} / \mathrm{mg}$ of dry matter. At the same time, the caloric content of caviar is quite low - only $3.8-3.9 \mathrm{cal} / \mathrm{mg}$ of dry matter with an organic matter content of about $85 \%$. The fryes are more caloric $-4.1-4.3 \mathrm{cal} / \mathrm{mg}$ of dry matter. It because of their main food is so highcalorie zooplankton.

As a result of analysis of the intestinal contents of the fish we caught, it was found that the most common food items for adult fishes were plankto-benthic and benthic representatives of marine crustaceans Antarcturus polaris (Hodgson, 1902), Cymodocella tubicauda Pfeffer, 1887, Paramoera walkeri (Stebbing, 1906), Orchomene cavimanus Stebbing, 1888, different polychaetes. The fish fryes and fragments of octocorallians even were found in some stomachs.

The food that pass to the stomach of fish has a caloric content that differs significantly in energy value with a maximum of $5.6 \mathrm{cal} / \mathrm{mg}$ of dry matter.

\section{Benthic fauna}

Some of the obtained data are presented in Tables 3, 4 and Fig. 1.

A common representative of the bottom fauna of the Isopoda order is $C$. tubicauda. Caloric content was determined for $C$. tubicauda in eggs, embryos, and in different age groups. Eggs have the highest caloric content. Their energy value is in the range of $5.9-7.1 \mathrm{cal} / \mathrm{mg}$ of dry matter with an organic content of about $93.7 \%$ and water $45-54 \%$, in some cases

Table 1. Energy assessment of some representatives of the ichthyofauna of the Cosmonauts Sea and the Cooperation Sea sampled during the BAE (2013-2018)

\begin{tabular}{|l|l|c|c|}
\hline \multicolumn{1}{|c|}{ Taxon } & \multicolumn{1}{|c|}{ Sampling site } & Ash \% & $\begin{array}{c}\text { Cal/mg } \\
\text { dry matter }\end{array}$ \\
organic matter \\
Trematomus pennellii (Regan, 1914) & Cooperation Sea, Nella Fjord & 6.1 & 4.06 \\
Trematomus bernacchii Boulenger, 1902 & Cooperation Sea, Nella Fjord & 8.0 & 4.57 \\
Pagothenia borchgrevinki (Boulenger, 1902) & Cosmonauts Sea, Lazurnaya Bay & 4.8 & 4.77 \\
\hline
\end{tabular}




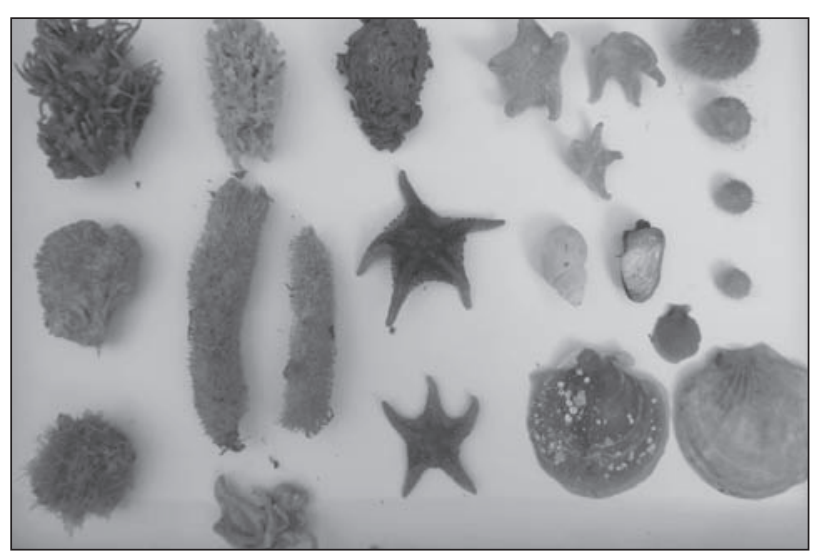

Fig. 1. Examples of some species of macrozoobentos of the East Antarctic seas

about $37 \%$. As for Isopoda representatives, the caloric content of the crustacean Aega sp. $-3.95 \mathrm{cal} / \mathrm{mg}$ of dry matter or $4.98 \mathrm{cal} / \mathrm{mg}$ of organic matter with an ash content of about $21 \%$.

The caloric content of representatives of marine spiders (Pantopoda) is generally small and at the average of $3.6 \mathrm{cal} / \mathrm{mg}$ of dry matter or $4.3 \mathrm{cal} / \mathrm{mg}$ of organic matter with an ash content of about $16 \%$.

For the sublittoral asteroideans, the caloric content of body matter was determined for five species:
Odontaster validus Koehler, 1906 (1.7-2.7 cal/mg of dry matter), Lophaster sp. (3.2 cal/mg), Acodontaster sp. (2.1 cal/mg), Leptychaster sp. (3.5 cal/mg) with variation in the organic matter content in their body around $47-53 \%$.

Ophiuroids (Ophiuroidea) have low caloric content, same as for asteroideans, $0.95-2.56 \mathrm{cal} / \mathrm{mg}$ of dry matter.

It is noteworthy that sea urchins (Echinoidea), in particular the species Sterechinus neumayeri (Meissner, 1900), are one of the lowest-calorie animals living in the sea $-0.6-0.9 \mathrm{cal} / \mathrm{mg}$ of dry matter. Moreover, this species dominates in abundance in benthic communities of the studied zones of the seas (Fig. 2).

In sea urchins with eggs up to $2.5-5.2 \mathrm{~g}$ by weight, the organic matter content reaches $30 \%$. The energy value of the ovaries (having a brown color) is $4.3 \mathrm{cal} /$ mg of dry matter with $82.1 \%$ of organic matter. The testicles are more high-caloric $-4.7 \mathrm{cal} / \mathrm{mg}$ of dry matter with $88 \%$ of organic matter. The filled guts of these urchins have a caloric content only $2.4 \mathrm{cal} / \mathrm{mg}$ of dry matter. In another species of sea urchins, $A b a-$ tus sp., the energy value of caviar was only $4.3-$ $4.6 \mathrm{cal} / \mathrm{mg}$ of dry matter with an organic matter content of about $85 \%$.

Table 2. Energy assessment of some representatives of the ichthyofauna of the Davis Sea based on the collections during the XVIth Soviet Antarctic Expedition (1970-1971)

\begin{tabular}{|l|c|c|c|c|}
\hline \multicolumn{1}{|c|}{ Taxon } & Stage & $\begin{array}{c}\text { Cal/mg } \\
\text { dry weight }\end{array}$ & $\begin{array}{c}\text { \% organic } \\
\text { matter }\end{array}$ & $\%$ water \\
\hline Pagothenia borchgrevinki (Boulenger, 1902) & imago & 3.91 & 85.37 & 80.5 \\
Trematomus sp. & imago & 3.86 & 83.80 & - \\
P. borchgrevinki (Boulenger, 1902) & fry & 4.10 & - & 76.9 \\
P. borchgrevinki (Boulenger, 1902) & fry & 4.23 & - & 77.2 \\
P. borchgrevinki (Boulenger, 1902) & juvenile & 4.05 & 94.17 & - \\
P. borchgrevinki (Boulenger, 1902) & juvenile & 4.31 & 94.07 & - \\
P. borchgrevinki (Boulenger, 1902) & juvenile & 3.74 & 85.88 & - \\
Trematomus bernacchii Boulenger, 1902 & imago & 3.99 & 88.31 & 80.66 \\
Tr. bernacchii Boulenger, 1902 & caviar 1 mm & 3.84 & 86.05 & 82.63 \\
P. borchgrevinki (Boulenger, 1902) & caviar 4 mm & 3.93 & 84.73 & - \\
P. borchgrevinki (Boulenger, 1902) & embryo & 4.05 & - & - \\
P. borchgrevinki (Boulenger, 1902) & larvae & 4.20 & - & - \\
\hline
\end{tabular}


Holothurians, which inhabit the cold waters of the Antarctic in a big abundance, might be as potentially commercial species. Within the Holothuroidea Class, the energy value of Cucumaria sp., Psolus sp. and two more species were determined. As in most of the examined animals, the highest caloric content is in the reproductive organs, their caloric content was $4.7 \mathrm{cal} / \mathrm{mg}$ of dry matter (testes - more than $5 \mathrm{cal} / \mathrm{mg}$ of dry matter), with an organic matter content of $92.3 \%$.

The common for Antarctic waters species of Nemertea Phylum, Parborlasia corrugatus (McIntosh, 1876), having a rather high caloric content of organic matter (on average about $4.7 \mathrm{cal} / \mathrm{mg}$ ), contains only $3-6 \%$ of ash (in some cases up to $20 \%$ ).

Among the representatives of Polychaeta Class, $\mathrm{Po}$ tamilla antarctica (Kinberg, 1866) is leading by abundance and biomass (organic content is $85 \%$ ) and has caloric values of about $3.5 \mathrm{cal} / \mathrm{mg}$.

Of the other polychaete worms, Pionosyllis kerguelensis (McIntosh, 1885) has a caloric content of $2.8 \mathrm{cal} / \mathrm{mg}$ of dry matter with an organic matter content of about $71 \%$. Representatives of Aphroditidae have $3.2 \mathrm{cal} / \mathrm{mg}$ of dry matter with an organic content of about $84.5 \%$.

Among molluscs, the most common is Antimargarita dulcis (E. A. Smith, 1907) (Class Gastropoda). When determining the energy value of various age and size groups of this mollusc (in the range of 6.0 $142.0 \mathrm{mg}$ of wet weight or $2.9-87.2 \mathrm{mg}$ of dry weight with a shell height of $2.3-8.2 \mathrm{~mm}$ ), it was found that the caloric content of body matter (without shells) varied within $4.12-4.22 \mathrm{cal} / \mathrm{mg}$ of dry matter or $4.71-4.86 \mathrm{cal} / \mathrm{mg}$ of organic matter (with an ash content of $11-14 \%$ in body dry matter). The energy value of Antarctic nudibranch molluscs is in the range 3.42$3.70 \mathrm{cal} / \mathrm{mg}$ of dry matter or $4.26-4.74 \mathrm{cal} / \mathrm{mg}$ of organic matter with an organic matter content of 78 $80.2 \%$ in body dry matter. Some of Clione spp. have the caloric content $3.71 \mathrm{cal} / \mathrm{mg}$ of dry matter, which is equivalent to about $41 \mathrm{cal}$ (wet weight is $285 \mathrm{mg}$, dry one is $11 \mathrm{mg}$ ). Representatives of bivalves (Class Bivalvia) of the Antarctic, Philobrya sublaevis Pelseneer, 1903 have a caloric content of $3.7 \mathrm{cal} / \mathrm{mg}$ of dry matter. The Antarctic scallop Adamussium colbecki (E. A. Smith, 1902) from the Davis Sea has a caloric content

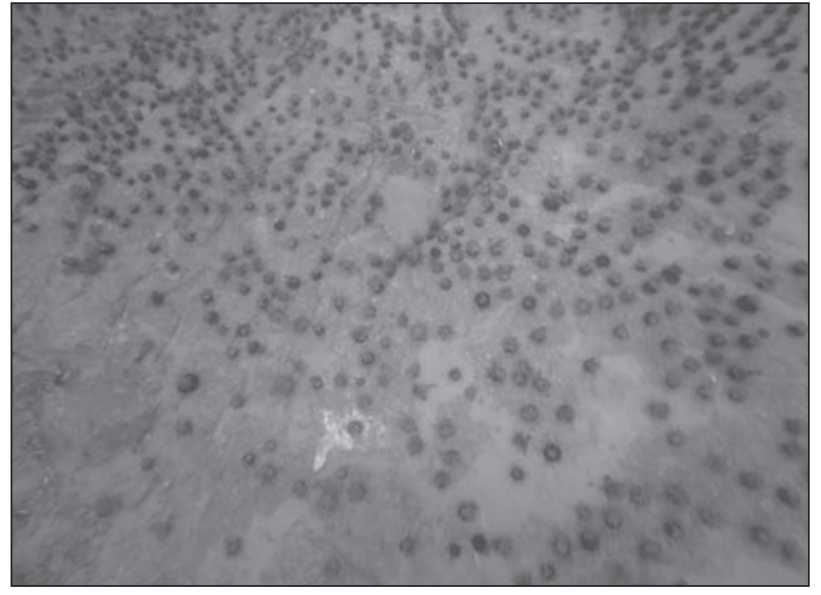

Fig. 2. Sea urchins Sterechinus neumayeri at the depth of $37 \mathrm{~m}$ in the Cosmonauts Sea, Lazurnaya bay

of $3.5-4.2 \mathrm{cal} / \mathrm{mg}$ of dry matter or $4.12-4.86 \mathrm{cal} / \mathrm{mg}$ of organic matter.

From the rest of representatives of the Animal Kingdom living in the littoral zone of the sea, the following are worth of mentioning due to their high representation:

- parasite of sea urchins Abatus, belonging to the infraclass Ascothoracida sp., which have a caloric content of $3.3 \mathrm{cal} / \mathrm{mg}$ of dry matter with $53.1 \%$ of organic matter;

- tanaidacean Nototanais antarcticus (Hodgson, 1902) $-3.4 \mathrm{cal} / \mathrm{mg}$ of dry matter with $62.7 \%$ of organic matter;

- amphipods Caprellidae sp. - the egg-bearing females have $3.2 \mathrm{cal} / \mathrm{mg}$ of dry matter $(70.5 \%$ of organic matter), juveniles $-3.4 \mathrm{cal} / \mathrm{mg}$ of dry matter ( $80.8 \%$ of organic matter) and Hyperiidea sp. -3.8 $\mathrm{cal} / \mathrm{mg}$ of dry matter ( $74.25 \%$ of organic matter).

It should also be noted that the sea sponges, having such a low caloric content $1.5 \mathrm{cal} / \mathrm{mg}$ of dry matter, reach an energy equivalent of more than $1000 \mathrm{kcal}$.

Ascidia, which is widespread in the Antarctic seas, has a caloric content of about $2 \mathrm{cal} / \mathrm{mg}$ of dry matter (51\% of organic matter, $93.5 \%$ of water and weight over $1 \mathrm{~kg}$ ).

\section{Amphipod crustaceans of benthal}

This group has been separated since its representatives live not in bentic biotopes only, but during the 
ontogenesis also some stages are components of under-ice cenosis.

Amphipods $O$. cavimanus are one of the main prey for birds and fishes which live in the Antarctic seas. By the time of maturity, the bodies of the females become yellow, and after are red (due to fatty inclusions). The caloric content of the orchomen body varies depending on season. The caloric value maximum specimens reach in late May - early June, i.e. in the middle of the Antarctic winter. At this time of the year, orchomen eggs have the highest caloric content $(6.6 \mathrm{cal} / \mathrm{mg})$, and crustaceans contain about $4.6 \mathrm{cal} / \mathrm{mg}$ of dry matter with about $20 \%$ of ash in them.

Typical representative of Amphipoda Order is $P$. walkeri. Their eggs have the maximum calorie value up to $5.3 \mathrm{cal} / \mathrm{mg}$ of dry matter and about $92 \%$ of organic substance content. The caloric content of females with eggs reaches $4.4 \mathrm{cal} / \mathrm{mg}$ of dry matter with an organic matter content of 75-77\%. The juveniles appear simultaneously with the beginning of diatom algae development, which is associated with the formation of intra-water ice.

It was revealed that a change in the caloric content of another species of amphipods, Cheirimedon fougneri Walker, 1903, during growing. Their eggs have the maximum caloric value $5.95 \mathrm{cal} / \mathrm{mg}$ of dry matter either $6.6 \mathrm{cal} / \mathrm{mg}$ of organic matter (10\% of ash). The caloric value of $C$. fougneri gradually decreases until $4.5-4.8 \mathrm{cal} / \mathrm{mg}$ of dry matter with $23-24 \%$ of ash during growing.

Representatives of the ice fauna also include the amphipod Eusirus antarcticus Thomson, 1880, which has a caloric content of $4.0 \mathrm{cal} / \mathrm{mg}$ of dry matter with $71.3 \%$ of organic matter in the body dry matter. Thus, the inhabitants of the cryopelagic biocenosis gene-

Table 3. Energy assessment of some representatives of the benthic biota of the Cosmonauts Sea and the Cooperation Sea sampled during the BAE (2013-2018)

\begin{tabular}{|c|c|c|c|c|}
\hline Taxon & Sampling site & Ash \% & $\begin{array}{c}\mathrm{Cal} / \mathrm{mg} \\
\text { dry matter }\end{array}$ & $\begin{array}{c}\mathrm{Cal} / \mathrm{mg} \\
\text { organic matter }\end{array}$ \\
\hline Phaeophyta gen. sp. & Cooperation Sea, Nella Fjord & 35.8 & 2.64 & 4.11 \\
\hline Porifera gen. sp.1 & Cooperation Sea, Nella Fjord & 61.4 & 1.52 & 3.94 \\
\hline Porifera gen. sp. 2 & Cooperation Sea, Nella Fjord & 75.5 & 0.73 & 2.98 \\
\hline Alcionaria sp. & Cooperation Sea, Nella Fjord & 15.8 & 3.99 & 4.74 \\
\hline Actiniaria gen. sp. & Cooperation Sea, Nella Fjord & 9.8 & 4.20 & 4.66 \\
\hline Laternula sp. (body without shell) & Cooperation Sea, Nella Fjord & 22.3 & 3.20 & 4.12 \\
\hline Gastropoda gen. sp. (body without shell) & Cooperation Sea, Nella Fjord & 15.2 & 5.03 & 5.93 \\
\hline Bivalvia gen. sp. (body without shell) & Cooperation Sea, Nella Fjord & 20.1 & 3.24 & 4.04 \\
\hline Nemertea gen. sp. & Cooperation Sea, Nella Fjord & 71.0 & 0.94 & 3.24 \\
\hline Polychaeta gen. sp., body without envelope (tube) & Cooperation Sea, Nella Fjord & 9.9 & 4.21 & 4.67 \\
\hline Holothuroidea sp. & Cooperation Sea, Nella Fjord & 16.0 & 4.10 & 4.88 \\
\hline Asteroidea gen. sp. 1 & Cooperation Sea, Nella Fjord & 50.6 & 1.93 & 3.91 \\
\hline Asteroidea gen. sp. 2 & Cooperation Sea, Nella Fjord & 52.7 & 2.13 & 4.50 \\
\hline Asteroidea gen. sp. 3 & Cosmonauts Sea, Lazurnaya Bay & 56.6 & 2.07 & 4.77 \\
\hline Asteroidea gen. sp. 4 & Cosmonauts Sea, Lazurnaya Bay & 64.4 & 1.51 & 4.24 \\
\hline Sterechinus neumayeri (Meissner, 1900) (caviar) & Cooperation Sea, Nella Fjord & 18.0 & 4.09 & 4.99 \\
\hline Amphipoda gen. sp. & Cooperation Sea, Tulenja Bay & 39.7 & 3.50 & 5.80 \\
\hline Ascidiacea gen. sp. & Cooperation Sea, Nella Fjord & 38.8 & 2.61 & 4.26 \\
\hline Ascidiacea gen. sp. & Cooperation Sea, Nella Fjord & 23.8 & 3.16 & 4.15 \\
\hline Ascidiacea gen. sp. & Cooperation Sea, Nella Fjord & 38.0 & 2.36 & 3.81 \\
\hline
\end{tabular}


Table 4. Energy assessment of individual representatives of the benthic and other biota of the Davis Sea based on the collections of the XVIth Soviet Antarctic Expedition (1970-1971)

\begin{tabular}{|c|c|c|c|c|c|}
\hline Taxon & $\begin{array}{l}\mathrm{Cal} / \mathrm{mg} \\
\text { dry matter }\end{array}$ & $\begin{array}{c}\% \text { organic } \\
\text { matter }\end{array}$ & $\begin{array}{c}\mathrm{Cal} / \mathrm{mg} \\
\text { organic matter }\end{array}$ & $\begin{array}{c}\text { Water } \\
\text { content, \% }\end{array}$ & $\begin{array}{c}\mathrm{Cal} / \mathrm{mg} \text { organic } \\
\text { matter in eggs }\end{array}$ \\
\hline Spongia sp. & 1.5 & 43.6 & 3.4 & 74 & - \\
\hline Hydrozoa gen. sp. & 0.7 & 21.5 & 3.3 & 56 & - \\
\hline Scyphozoa gen. sp. & 2.2 & 40.0 & 5.5 & 97 & - \\
\hline Eunephtia sp. & 2.8 & 66.3 & 4.2 & 90 & - \\
\hline Actinaria sp. & 4.0 & 83.4 & 4.8 & 82 & - \\
\hline Caligorgia ventilabrum Studer, 1878 & 1.2 & 24.4 & 4.9 & - & - \\
\hline Primnoisis antarctica (Studer, 1878) & 1.2 & 24.4 & 4.9 & - & - \\
\hline Ctenophora gen. sp. & 2.1 & 52.6 & 4.0 & 95 & - \\
\hline Nematoda gen. sp. & 4.0 & 80.0 & 5.0 & 51 & - \\
\hline Parborlasia corrugatus (McIntosh, 1876) & 4.4 & 93.7 & 4.7 & 85 & - \\
\hline Potamilla antarctica Gravier, 1907 & 3.6 & 85.2 & 4.2 & 79 & - \\
\hline Eusyllis kerguelensis McIntosh, 1885 & 2.8 & 71.1 & 4.0 & - & - \\
\hline Aphroditidae gen. sp. & 3.2 & 84.5 & 3.8 & 83 & - \\
\hline Polychaeta gen. sp.1 & 3.2 & 74.2 & 4.3 & - & - \\
\hline Polychaeta gen. sp. 2 & 2.0 & 58.6 & 3.4 & 91 & - \\
\hline Lamellariidae gen. sp. & 3.7 & 78.0 & 4.7 & 96 & - \\
\hline Clione sp. & 3.7 & - & - & 96 & - \\
\hline Laternula elliptica (King \& Broderip, 1832) & 3.7 & 88.4 & 4.1 & 64 & 4.8 \\
\hline Adamussium colbecki (E. A. Smith, 1902) & 3.6 & - & - & 80 & - \\
\hline Gastropoda gen. sp. & 4.2 & 87.8 & 4.8 & - & - \\
\hline Antimargarita dulcis (E. A. Smith, 1907) & 3.4 & 80.2 & 4.2 & - & - \\
\hline Antarcturus polaris (Hodgson, 1902) & 2.5 & 60 & 4.2 & 74 & 6.5 \\
\hline Cymodocella tubicauda Pfeffer, 1887 & 2.5 & 46.5 & 5.4 & 63 & 7.6 \\
\hline Aega sp. & 4.0 & 79.2 & 5.1 & 65 & - \\
\hline Paramoera walkeri (Stebbing, 1906) & 3.8 & 75.0 & 5.1 & - & 5.7 \\
\hline Orchomene cavimanus (Stebbing, 1888) & 3.9 & 77.0 & 5.1 & 78 & - \\
\hline Eusirus antarcticus Thomson, 1880 & 4.0 & 71.3 & 5.6 & 75 & 6.6 \\
\hline Prostebbingia gracilis (Chevreux, 1912) & 2.5 & - & - & 73 & - \\
\hline Cheirimedon fougneri Walker, 1903 & 4.7 & 78.4 & 6.0 & 56 & 6.0 \\
\hline Caprellidae gen. sp. & 3.3 & 80.8 & 4.1 & - & - \\
\hline Hyperia sp. & 3.8 & 74.2 & 5.1 & 89 & - \\
\hline Dendrogastridae gen. sp. & 3.2 & 53.1 & 6.3 & - & - \\
\hline Euphausia superba Dana, 1852 & 5.3 & 83.6 & 6.3 & 78 & - \\
\hline Nototanais antarcticus (Hodgson, 1902) & 3.4 & 62.7 & 5.4 & - & - \\
\hline Ascothoracida gen. sp. & 3.3 & 53.1 & 6.2 & - & - \\
\hline Calanus propinquus Brady, 1883 & 6.2 & 97.6 & 6.4 & - & - \\
\hline Calanus simillimus Giesbrecht, 1902 & 4.3 & 97.6 & 4.4 & - & - \\
\hline Pantopoda gen. sp. & 3.6 & 84.2 & 4.3 & - & - \\
\hline Odontaster validus Koehler, 1906 & 2.5 & 55.7 & 4.5 & 75 & - \\
\hline Acodontaster sp. & 2.1 & 50.0 & 4.2 & 75 & - \\
\hline Lofaster sp. & 3.3 & 61.2 & 5.4 & 75 & - \\
\hline Leptychaster magnificus (Koehler, 1912) & 3.5 & 62.7 & 5.6 & 83 & - \\
\hline Podasterias sp. 1 & 2.1 & 52.1 & 4.0 & - & - \\
\hline Podasterias sp.2 & 2.1 & 55.1 & 3.8 & - & - \\
\hline Ophiosparte gigas Koehler, 1922 & 2.2 & 44.0 & 5.0 & 74 & - \\
\hline Ophiosparte gigas Koehler, 1922 & 1.1 & 32.0 & 3.4 & - & - \\
\hline
\end{tabular}


End of Table 4.

\begin{tabular}{|c|c|c|c|c|c|}
\hline Taxon & $\begin{array}{c}\mathrm{Cal} / \mathrm{mg} \\
\text { dry matter }\end{array}$ & $\begin{array}{l}\% \text { organic } \\
\text { matter }\end{array}$ & $\begin{array}{c}\mathrm{Cal} / \mathrm{mg} \\
\text { organic matter }\end{array}$ & $\begin{array}{c}\text { Water } \\
\text { content, \% }\end{array}$ & $\begin{array}{c}\mathrm{Cal} / \mathrm{mg} \text { organic } \\
\text { matter in eggs }\end{array}$ \\
\hline Sterechenus neumayeri (Meissner, 1900) & 1.6 & 40.0 & 4.0 & - & - \\
\hline Abatus sp.1 & 1.0 & 26.0 & 3.8 & 23 & 5.2 \\
\hline Abatus sp. 2 & 1.2 & 12.6 & 9.5 & 26 & 5.4 \\
\hline Cucumaria spatha Cherbonnier, 1941 & 1.2 & 15.4 & 7.7 & 27 & - \\
\hline Psolus sp. 1 & 3.7 & 77.1 & 4.8 & 90 & 4.8 \\
\hline Psolus sp.2 & 2.2 & 54.5 & 4.0 & 80 & - \\
\hline Crinoidea gen. sp. & 3.5 & 79.2 & 4.4 & 85 & 5.1 \\
\hline Promachocrinus kerguelensis Carpenter, 1879 & 3.4 & 79.2 & 4.3 & - & - \\
\hline Promachocrinus kerguelensis Carpenter, 1879 & 1.4 & 37.9 & 3.7 & - & - \\
\hline Promachocrinus kerguelensis Carpenter, 1879 & 2.5 & 50.0 & 5.0 & - & - \\
\hline Flustra sp. & 1.7 & 50.2 & 3.4 & 73 & - \\
\hline Sagitta sp. & 2.3 & - & - & 94 & - \\
\hline Ascidiaceae gen. sp. & 1.9 & 51.0 & 3.7 & 93 & - \\
\hline
\end{tabular}

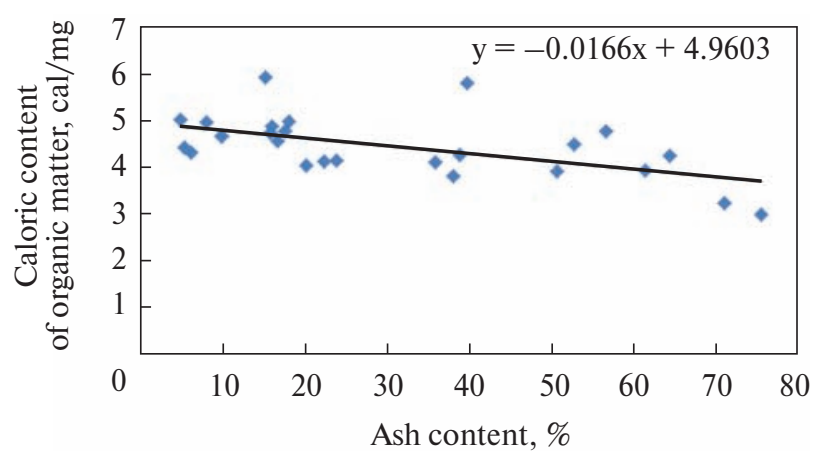

Fig. 3. The relationship of the caloric content of organic matter to the ash content of various representatives of the Antarctic biota (samples from 2017-2018)

Table 5. Energy equivalent of the zoobenthos biomass of the sublittoral in the Davis Sea (modified from Giginyak, 1975)

\begin{tabular}{|c|c|c|c|}
\hline Depth (m) & $\begin{array}{c}\text { Biomass } \\
\left(\mathrm{raw} / \mathrm{m}^{2}\right)\end{array}$ & $\begin{array}{c}\text { Biomass } \\
\left(\mathrm{dry} \mathrm{g} / \mathrm{m}^{2}\right)\end{array}$ & $\begin{array}{c}\text { Energy } \\
\text { equivalent } \\
\text { of biomass } \\
\left(\mathrm{kcal} / \mathrm{m}^{2}\right)\end{array}$ \\
\hline $0-15$ & $20-25$ & $4-5$ & 17 \\
$15-20$ & 500 & 100 & 350 \\
$20-30$ & 1000 & 200 & 700 \\
$30-40$ & 3000 & 600 & 2100 \\
100 & 500 & 100 & 350 \\
\hline
\end{tabular}

\section{4}

rally have a high caloric content of the body substance, which is about $4-5 \mathrm{cal} / \mathrm{mg}$ of dry matter, with a relative ash content of $20-30 \%$ (in dry matter).

\section{DISCUSSION}

Thus, we have determined that the caloric content of some representatives of the ice, sub-ice and benthic fauna varies widely and, in general, depends on the quantity and quality of organic matter in certain species, and also depends on the season. These results show that the content of organic matter in Antarctic species varies from $16.8 \%$ to $98 \%$, and caloric content from 0.5 to $7.3 \mathrm{cal} / \mathrm{mg}$ of dry matter.

Biological studies conducted at different years allowed to calculate the approximate energy reserve of animals using the macrozoobenthos of the Davis Sea (East Antarctica) as an example (Table 5).

As can be seen from the table, the total biomass of animals varies over the horizons and can reach $3 \mathrm{~kg}$ per $\mathrm{m}^{2}$ at the depth of 30-40 meters. It should be taken into account that these are average values and they largely depend on the biotope and, to some extent, on the migration of icebergs, which are able to destroy the benthic attached forms - sponges, ascidians, actiniarians.

There are a number of factors affecting the caloric content of aquatic organisms: the size of organisms, ISSN 1727-7485. Ukrainian Antarctic Journal. 2019, № 2(19) 
individual and seasonal changes in chemical composition, physiological state, environmental temperature, quantity and quality of food, etc. (Norrbin, Bamstedt, 1984, Orejas, 2001, Núñez-Pons, Avila, 2014, Harmelin-Vivien et al., 2019). These factors, both as single as well as in combination, affect the ratio between the organic and mineral fractions of the examined substance, as well as, which is important, between the separate components of the organic matter, which determines the caloric value of hydrobionts. For a large number of marine and freshwater organisms, the relationship between caloric content and the content of organic and mineral fractions of dry matter can be considered as linear. An analysis of the data obtained in this study confirms this statement (Fig. 3).

\section{CONCLUSIONS}

In general, we can conclude that the caloric values of marine zoobenthos in all three studied seas, the Davis, Cosmonauts and Cooperation are close to each other.

To low-calorie representatives of the Antarctic flora and fauna correspond the high ash levels of their body substance. Such organisms whose caloric content of dry matter does not exceed 1-1.5 calories are the bottom complex, such as hydroids, sponges, bryozoans, gorgonarians, ophiuroids, sea urchins, and crinoids. Diatom phytoplankton also belongs to the low caloric content item.

The group of animals which are in range of 1.5-3.5 calories includes jellyfish, soft anthozoa, ctenophores, almost all polychaetes, some nudibranch molluscs, most of the isopods, some of amphipods, tanaidaceans, asteroideans, ophiuroids and holothurians. This group also includes ascidians. As a rule, the content of organic matter in representatives of this group does not exceed $60-70 \%$. Animals belonging to this group are dominant in their abundance and biomass and make up the bulk of the ice, planktonic and benthic populations of the Antarctic sublittoral.

Animals whose caloric content is in the range of 3.5-5.0 calories are the high-calorie ones. Their organic matter content usually exceeds $80 \%$ of dry weight. This group includes sea anemones, nematodes, nemerteans, the body of molluscs, some nudibranch and pteropod molluscs, most of amphipods, some species of isopods, euphausiaceans, sea spiders, some holothurians, and representatives of the Calanus genus. Fishes belong to this group also.

Representatives of the cryopelagic biocenosis, those are mainly various amphipods, are also belong to the group of high-calorie organisms.

Especially interesting animals of which the caloric content of body is above 5 calories. Usually these are representatives of zooplankton belonging to the Crustacea Subphylum. Species such as C. propinquus, C. acutus and other calanoids, euphausiids contain about $90 \%$ of organic matter with a high fat content. In certain seasons the caloric content of calanoids can exceed 7 calories per unit of dry matter. Having such a high calorific value, due to the high content of organic matter and occupying a dominant position in plankton biomass, such species play an important role in the overall energy assessment of total plankton.

The energy equivalents of the body of some representatives of zooplankton and zoobenthos can reach $1000 \mathrm{kcal}$ (giant jellyfish, sponges). The energy equivalent of the biomass of animals in certain areas of the bottom or under-ice surface can also reach large values. So, for example, the energy equivalent of the biomass of animals of the ice fauna in some cases can reach values of about $150 \mathrm{kcal} / \mathrm{m}^{2}$.

Acknowledgments. The authors are sincerely thankful to the experts from the Zoological Institute of the Russian Academy of Sciences - B.I. Sirenko, I.S. Smirnov, A.V. Neyelov and other researchers for the taxonomic identification. We express special acknowledgment to the pioneer divers in the Antarctic who have left us already, Evgeny Nikolaevich Gruzov and Alexander Mikhailovich Sheremetevskiy. Without their enthusiasm and sacrifice the richest material in the Davis Sea would not have been collected. Our thanks go to the permanent assistant of biologists during collecting the material in the Antarctic, the head of the BAE A.A. Gaidashov - the unique material has been collected due to his diving under the ice. 


\section{REFERENCES}

Davis, N. D. 1993. Caloric content of oceanic zooplankton and fishes for studies of salmonid food habits and their ecologically related species. (NPAFC Doe.) FRI-UW-93 12. Fisheries Research Institute, University of Washington, Seattle. 10.

Finlay, B.J., Uhlig, G. 1981. Calorific and carbon values of marine and fresh water Protozoa. Helgolander Meeresunters, 34, 401-412 (1981). https://doi.org/10.1007/BF01995913.

Giginyak, Y.G. 1975a. Nekotorye osobennosti biologii i kaloriinost bespozvonochnyh sublitorali Antarktiki. [Some features of biology and caloric of invertebrates sublittoral zone of Antarctic]. Avtoref dis na soisk uch step kand biol nauk [Abstract of thesis of Candidate of Biological Sciences]. Minsk. 23.

Giginyak, Y.G. 19756. Razmerno-vesovaia harakteristika, plodovitost, energeticheskaia otcenka Cymodocella tybicauda (Isopoda) [Size-weight peculiarities, fecundity, energy assessment of Cymodocella tybicauda (Isopoda)]. Trudy 1 Resp simp po ekologo-energ aspektam rosta i razm vodn bespozv [Proceedings of the 1 Rep. symp. on ecologycal and energy aspects of growth and breeding of the aquatic invertebrates]. Minsk.

Giginyak, Y.G. 1979. Kaloriinost vodnyh bespozvonochnyh zhivotnyh [Caloric content of aquatic invertebrates].Obshchie osnovy izucheniia vodnykh ekosistem [General basics of studying of the aquatic ecosystems]. L.: Nauka. 6-16.

Giginyak, Y.G. 1983. Kaloriinost vodnyh bespozvonochnyh Antarctiki [Caloric content of Antarctic aquatic invertebrates]. Vses. nauchn. konf. Sy'r'evy'e resursy'Antarkticheskoj zony' okeana i problemy' ikh raczional'nogo ispol'zovaniya [All-Union scientific conf. Raw materials of the Antarctic Ocean zone and problems of their rational use]. Kerch.

Giginyak, Y. 2013. Dinamics of oxygen content in surface layer of water in Davis sea (Eastern Antarctica). VI Mizhnarodna Antarktychna Konferentsiia [VI International Antarctic Conference]. Kyiv, May 15, 2013, 135-136.

Giginyak, Y.G. 2014. Energeticheskaia otcenka bioty sublitorali vysokoshirotnogo moria Antarktiki [Energy assessment of sublittoral biota of high-latitude Antarctic seas]. Materialy 1 Mezhdunarodnoi nauchno-prakticheskoi konferentsii 26-29 maia $2014 \mathrm{~g}$. Naroch [Materials of the I International scientifically-practical conference, Naroch, on May, 26-29th, 2014]. Minsk: Ekoperspektiva. 46-51.

Giginyak, Y.G., Lukashanets, D.A., Gaidashov, A. A. 2018. Opyt ispolzovaniia teleupravliaemogo podvodnogo apparata "Gnom" pri otcenke zapasov morskih biologicheskih resursov v usloviiah Antarktiki [Experience of using the remote-controlled underwater vehicle "Gnom" for assessment of marine biological resources at the Antarctic conditions]. Materialy 3 Mezhdunarodnoi nauchno-prakticheskoi konferentsii 17-19 sentiabria $2018 \mathrm{~g}$. [Materials of the 3rd Interna- tional Scientific and Practical Conference, September 1719, 2018]. Minsk, 106-113.

Giginyak, Y., Grusov, E. 2009. Hydrobiological researches of coastal bottom communities in Davis sea (Antarctica). International Antarctic conference IAC 2009. International Polar Year in Ukraine: results and horizons, 2009, Kharkiv, Ukraine.

Giginyak, Y., Borodin, O. 2011-2012. Biological researches around the Belarusian Antarctic Expedition's Camp «Vechernyaya Mountain» (East Antarctica). Ukrainian Antarctic Journal, 10-11, 311-314.

Gruzov, E.N., Sheremetevskiy A.M. 1973. Biologicheskie issledovaniia v more Devisa, 1970-1972 gg. [Biological investigations in the Davis Sea, 1970-1972]. Trudy 16-oi Sov Antarkt eksped [Proceedings of the 16th Sov. Antarkt. Expedition].

Harmelin-Vivien,M., Bănaru, D., Dromard, C., Ourgaud, M., Carlotti, F. Biochemical composition and energy content of size-fractionated zooplankton east of the Kerguelen Islands. Polar Biology, 2019, 42 (3), 603-617.

Norrbin, F., Bamstedt, U. 1984. Energy contents in benthic and planktonic invertebrates of Kosterfjorden. Sweden. A comparison of energetic strategies in marine organism groups. Ophelia, 23, 47-64.

Núñez-Pons, L., Avila, C. 2014. Deterrent activities in the crude lipophilic fractions of Antarctic benthic organisms: chemical defences against keystone predators. Polar Res., 33. https://doi.org/10.3402/polar.v33.21624.

Orejas V.C. 2001. Role of benthic cnidarians in energy transfer processes in the Southern Ocean marine ecosystem (Antarctica). Rolle der bodenlebenden Nesseltiere im Stofffluß des marinen Ökosystems des Südpolarmeeres (Antarktis), Berichte zur Polar- und Meeresforschung (Reports on Polar and Marine Research), Bremerhaven, Alfred Wegener Institute for Polarand Marine Research, 395, 186. https://doi.org/10.2312/ BzPM_0 395_2001.

Platt, T., Irwin, B. 1973. Caloric content of phytoplankton. Limnol. Oceanogr., 18, 306-310. https://doi.org/10.4319/lo.1973. 18.2.0306.

Renk, H., Filarski, J., Ochocki, S., Piechowska, B. 1985. Energetic value and lipid content of the Baltic zooplankton. Oceanologia, 21, 99-108.

Schaafsma, F.L., Cherel, Y., Flores, H., van Franeker, J. A., Lea, M.-A., Raymond, B., van de Putte, A. P. 2018. Review: the energetic value of zooplankton and nekton species of the Southern Ocean. Marine Biology, 165, 129.

Wacasey, J.W., Atkinson, E.G. 1987. Energy values of marine benthic invertebrates from the Canadian Arctic. Mar. Ecol. Prog. Ser., 39, 243-250.

Received 27 November 2019 Accepted 02 January 2020 
Ю. Г. Гігіняк*, Д. О. Лукашанець, О. І. Бородін, В. Є. Мямін, В. М. Байчоров

Державне науково-практичне об’єднання «Науково-практичний центр Національної академії наук Білорусі з біоресурсів», вул. Академічна, 27, м. Мінськ, 220072, Білорусь

* Автор для кореспонденції: antarctida_2010@mail.ru

\section{Енергетична цінність біологічно-релевантних ресурсів субліторалі морів східної Антарктики}

Реферат. Мета роботи. Визначити енергетичну цінність представників окремих груп біоти морів Східної Антарктиди, виявити відмінності за показниками калорійності як різних таксонів, так і екологічних груп (кріопелагель, бенталь та ін.). Методика. Відбір проб відбувався за допомогою традиційних методів (бентосні пастки, збір при водолазних зануреннях), а також застосовувався дистанційний відбір проб (за допомогою телекерованих підводних апаратів). Енергетична цінність організмів визначена за допомогою методів мокрого спалювання. Результати. Вперше визначені енергетичні показники основних біологічних об'єктів субліторалі трьох морів Східної Антарктиди. Показано, що в досліджуваних районах субліторалі морів Космонавтів, Співдружності та Дейвіса домінантним видом морського зообентосу є морські їжаки виду Sterechinus neumayeri (Meissner, 1900). Визначено калорійність морських зірок, поліхет, немертин, губок, асцидій, голотурій, ракоподібних та деяких інших видів морської біоти. Показано, що вміст органічної речовини у антарктичних видів змінюється від 12 до 94\%, а калорійність від 0,7 до 7,3 кал/мг сухої речовини, максимальна калорійність відмічена для донних амфіпод і каланоід. Для морського зообентосу розраховані енергетичні еквіваленти на одиницю площі дна. Розраховано рівняння залежності калорійності речовини досліджуваного об'єкта від вмісту в ньому золи. Висновок. В цілому, можна дійти висновку, що величини калорійності морського зообентосу у всіх трьох досліджуваних нами морях близькі між собою. При цьому калорійність окремих представників морської фауни змінюється в значних межах і в цілому, залежить від пори року. Представникам флори і фауни Антарктики з низькими величинами калорійності відповідають високі величини зольності речовини їх тіла. В залежності від показників енергетичної цінності були виділені декілька груп морської біоти, які представлені різними таксонами.

Ключові слова: енергетична цінність, величина калорійності, морська біота, зообентос, фітопланктон, зоопланктон. 